\title{
Reseña
}

\section{Alternatives Sud: Changes le modile. Ici et maintenant?}

(vol.23-2016/3)

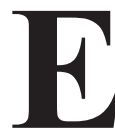
sta publicación belga del Centro Tricontinental, fundada por François Hontart, dedicada cada número a un tema central enfocado desde la perspectiva del Sur.

El imperativo de cambio es el tema del editorial elaborado por Frédéric Thomas (politólogo, CETRI, Bélgica). Comienza señalando que el año 1989 paree marcar el fracaso del comunismo y de toda alternativa al capitalismo, cuando en realidad lo que empezó a desenvolverse en la escena mundial fue la historia del fin: de un ciclo, de un modelo y de un dogma; con su consecuente serie de crisis sin fin: financiera, alimentaria, civilizatoria, moral.

Fue en América Latina, epicentro de proyectos alternativos, donde los 500 años de la conquista se tradujeron en medio milenio de resistencia, lo que equivale a que no hay más alternativas fuera de la lucha. Así, las alternativas del modelo y de los cambios por venir se basa en los siguientes aspectos: descolonización de los espíritus y de los territorios, redefinición de la economía, reconfiguración de lo político, un nuevo espíritu de la utopía, la eventual emergencia de nuevos sujetos históricos, los territorios de l'autonomía (institucionalización y representación, reterritorialización) y, finalmente, reinventar la revolución.

Para completar esta visión general desde el Sur, se plantean los siguientes temas desarrollados por especialistas de diferentes regiones:

- El desarrollo es la resistencia

- Decrecimiento, posdesarrollo y transición

- Alternativas al desarrollo y procesos de transmisión

- Perspectivas críticas sobre la soberanía alimentaria

- Para la defensa de los "comunes" (recursos administrados por una comunidad)

- Feminismos descoloniales

- Feminismo, descolonialidad y economía social 
- Foro social mundial: el desafío de la articulación

- Potenciar emergentes: resurgimiento del sur o reconfiguración de las élites?
Sin perder la esperanza, "En el Sur, han surgido numerosas listas para un cambio de paradigma en los últimos años. Estos se concretan a partir de conceptos claves como el buen vivir, la economía solidaria, el feminismo descolonial o los bienes comunes". (contraportada) 